\title{
Informing the increasing production of the health workforce in Bangladesh: evidence from a mapping exercise of health professional education institutions
}

\author{
Nuruzzaman $M^{1}$, Zapata $T^{2}$, Rahman $M M^{3}$
}

\begin{abstract}
This study aimed to evaluate the trend of production (2007-2016) and associated factors of seven health professionals i.e. physicians, dentists, diploma nurses, bachelor nurses, midwives, medical assistants and medical technologists in Bangladesh. The study team adopted a mapping approach to geographically locate all the health professional education institutions recognized by the Ministry of Health and Family Welfare (MOHFW). This was supported by a mixed-method design combining qualitative (e.g. group discussions and key informant interviews) and quantitative (questionnaire survey) methods. From 2007 to 2016, a total of 107,406 students graduated from all seven professional categories. Out of the total, about $40 \%$ belonged to the MBBS physician, 6\% dentists, 15\% medical assistants, $18 \%$ medical technologists, $21 \%$ nurses, and only $1 \%$ to the midwives. So, a skill-mix imbalance exists at the production level. Though the production had been on rising last 10 years, the production of the physicians was higher than any other professional categories. Feminization of the workforce is prominent as there was an average $14 \%$ increase of the female doctors than the male. The increasing production of health professionals needs to be supported by proper planning and policy interventions in order to avoid distortion of skill mix. Growing feminization of the workforce is also another area that requires special attention on the development of gender-sensitive employment conditions.
\end{abstract}

Key words: Health professionals, educational institutions, mapping, Bangladesh

1. Md Nuruzzaman, National Professional Officer-HRH, WHO Bangladesh, Dhaka,

2. Tomas Zapata, Regional Advisor-HRH, WHO South-East Asia Regional Office, New Delhi, India

3. Md Masudur Rahman, Deputy Director, Directorate General of Medical Education, Dhaka, Bangladesh

Address of correspondence: Md Nuruzzaman, National Professional Officer-HRH, WHO Bangladesh, Dhaka, Bangladesh, email: nuruzzamanm@who.int

\section{Background}

Human resources for health (HRH) are an indispensable component of the health system. They are the personification of the system as they heal and care, ease pain and suffering, prevent diseases and minimize risks $^{1}$. Therefore, for a health system to perform at optimal level, there is a need of adequate number and quality health workforce at all levels ${ }^{2}$. The "Global Human Resources for Health Strategy: Workforce 2030" that countries aiming to achieve Sustainable Development Goals (SDGs) including Universal Health

Bangladesh Journal of Medical Education 2021; 12(2); Nuruzzaman et al., publisher and licensee Association for Medical Education Bangladesh. This is an Open Access article which permits unrestricted non-commercial use, provided the original work is properly cited. 
Coverage (UHC) should have a threshold density of doctors, nurses and midwives of 44.5 per 10,000 population $^{3}$. Based on this threshold, the World Health Organization (WHO) projected an estimated additional requirement of 18 million health workforce all over the World ${ }^{3,4}$. The requirement is more prominent in low- and middle-income countries. Highest shortage by 2030 is projected in the South-East Asia Region which is about 4.7 million $^{5}$.

In 2015, Bangladesh along with other countries entered the era of SDGs and committed to achieve UHC by 2030. In 2019 , the density of doctors, nurses and midwives in Bangladesh reached to $8.3^{6}$, which is far below the globally recommended threshold of 44.5 per 10,000 population set in the 2016 "Global Human Resources for Health Strategy: Workforce 2030"3. Therefore, the shortage of health workers has become a bottleneck towards the journey to UHC.

There is no short-cut method to fulfill the gap or the shortage because producing an adequate number of health workforce and deploying them in most needed areas requires substantial amount of time and significant investments as well as a high level of political leadership and commitment.

In Bangladesh, the National Health Policy2011 recognizes the shortage of health workforce in the country and later the government adopted the Bangladesh Health Workforce Strategy-2015 ${ }^{7}$ The government took several initiatives to increase production and encouraged the private sector to come forward to contribute to the production of health workforce in the country. In this regard, revision of the nongovernment medical college establishment policy-2011 was made to facilitate establishment new medical and nursing colleges $^{8}$. Consequently, a significant upsurge of health workforce production through establishment of many education institutions has been observed since $2011^{9}$.

This upsurge was a reason to carry out a comprehensive mapping of health professional education institutions throughout the country for the first time. It covers those health professional education institutions, which are recognized by the Ministry of Health and Family Welfare (MOHFW). MOHFW bears the major responsibility of developing policies related to health professional education in the country as per the Rules of Business-2012 of the Government of Bangladesh ${ }^{10}$. The objectives of this mapping study were to evaluate (i) the growth of various types of health professional education institutions between 1971 and 2016 and their geographical distribution, (ii) trends in annual student enrolment of seven professional categories across a ten year period (2007-2016), (iii) the level of preservice attrition between enrolment and graduation, using data from the respective councils.

\section{Methods}

\section{Study design}

A mapping approach was adopted for this study because it is a systematic approach to understand the map of a profession, theory or practice and denotes how concepts are related in a visual way ${ }^{11}$. This helped to gather information to build a base for further research or to inform decision making. To assist the mapping approach, a mixed method study design was adopted to address the three study objectives to inform the increasing production of health workforce of seven categories. Figure-1 illustrates various policy issues and their influence on health workforce production (numbers and categories) in the health

Bangladesh Journal of Medical Education 2021; 12(2); Nuruzzaman et al., publisher and licensee Association for Medical Education Bangladesh. This is an Open Access article which permits unrestricted non-commercial use, provided the original work is properly cited. 
professional education sector in Bangladesh. This was reproduced from the health labour market framework used in the WHO's global health workforce strategy2030.

To achieve the first objective, the trend in annual establishment of all seven types of health professional education institutions was identified and geographically mapped out. Their divisional/regional distribution was scrutinized and then comparison was made between number of educational institutions and geographical divisions. For the second objective, 10 years of annual enrolment and graduation data were analyzed, covering the period 2007-2016. Enrolment was defined as the first-year admission of the students and graduation was defined as completion of the course or certificate awarded.

To meet the third objective- the assessment of the pre-service attrition between training enrolment and registration, annual registration data across 10 years were analyzed. Attrition is defined as the number of students who leave the program of study before it has finished ${ }^{12.13}$. Registration or licensing from the council is mandatory for all major health professionals.

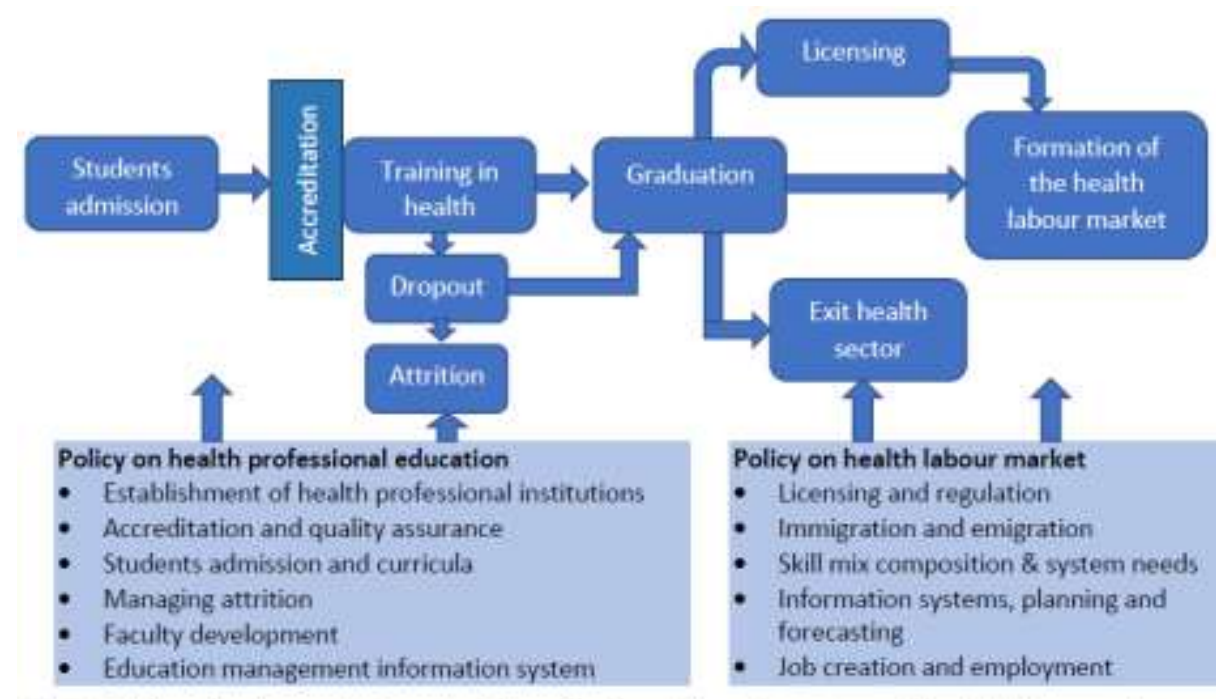

Fig 1. Public policy levers that shape health professional education sector and health labour market

\section{Project management}

\section{Technical advisory committee}

A technical advisory committee (TAC), consisting 19 members, was established by the Directorate General of Health Services under the Ministry of Health and Family Welfare (MOHFW) with 11 members from senior government officials, four health professional council officials, representative from professional organization, two officials from postgraduate medical University and one
WHO official. The role of the TAC was to guide and endorse the overall study based on mapping approach and its implementation.

\section{Technical working group}

A technical working group (TWG) was formed to guide and carry out the implementation of the mapping exercise. A total of eight members were in that group and among them, three were academicians (one was from the Institute of Health

Bangladesh Journal of Medical Education 2021; 12(2); Nuruzzaman et al., publisher and licensee Association for Medical Education Bangladesh. This is an Open Access article which permits unrestricted non-commercial use, provided the original work is properly cited. 
Technology Dhaka, one from the office of the Dean, Faculty of Medicine, University of Dhaka, and one was from the Centre for Medical Education), and five health professional education managers from the DGHS. Office of the Director for Medical Education and Health Manpower Development, DGHS worked as the Secretariat of the study. Two staff of the WHO Bangladesh provided technical support to this group.

\section{Scope and study duration}

This mapping study primarily focused on seven broad categories of health professionals who receive formal academic training from the institutions recognized by the MOHFW. It only considered the undergraduate health professionals education institutions offering the following academic certificates:

Table 1. Health professional categories and their respective education institutions

\begin{tabular}{|c|l|l|}
\hline SI. & Health professional categories and length of education & Institutions \\
\hline 1 & $\begin{array}{l}\text { Physician } \\
\text { Bachelor of Medicine and Bachelor of Surgery (MBBS), 5 } \\
\text { years + 1-year internship }\end{array}$ & $\begin{array}{l}\text { Medical College, Armed } \\
\text { Forces/Army Medical College }\end{array}$ \\
\hline 2 & $\begin{array}{l}\text { Dental Surgeon } \\
\text { Bachelor of Dental Surgery (BDS), 5 years + 1-year } \\
\text { internship }\end{array}$ & $\begin{array}{l}\text { Dental College, Dental Unit } \\
\text { attached with Medical College } \\
\text { Barse } \\
\text { Diploma of Science in Nursing (BScN), 4 years }\end{array}$ \\
\hline 4 & $\begin{array}{l}\text { Midwife } \\
\text { Diploma in Midwifery (DM), 3 Years }\end{array}$ & $\begin{array}{l}\text { Nursing College, Nursing } \\
\text { Institute }\end{array}$ \\
\hline 5 & $\begin{array}{l}\text { Medical Assistant } \\
\text { Diploma in Medical Faculty (DMF), 3 Years + 1-year } \\
\text { Internship }\end{array}$ & $\begin{array}{l}\text { Nursing College, Midwifery } \\
\text { Institute }\end{array}$ \\
\hline 6 & $\begin{array}{l}\text { Pharmacist } \\
\text { Diploma in Medical Technology (DMT) - Pharmacy, 3 years }\end{array}$ & $\begin{array}{l}\text { Medical Assistance Training } \\
\text { School (MATS) }\end{array}$ \\
\hline (IHT) of Health Technology \\
\hline 7 & $\begin{array}{l}\text { Medical Technologist } \\
\text { Diploma in Medical Technology (DMT), 3 years course (in } \\
\text { 10 disciplines -Lab Technology, Radiology, Radiotherapy, } \\
\text { Dental Technology, Physiotherapy, Sanitary Inspector } \\
\text { Training, Operation Theater (OT) Assistance, Intensive Care } \\
\text { (IC) Assistance, Prosthetics and Orthodontics and Cardiology }\end{array}$ & $\begin{array}{l}\text { Institute of Health Technology } \\
\text { (IHT) }\end{array}$ \\
\hline
\end{tabular}

This assessment focuses on the educational institutions registered with the MOHFW in a large extent and the Ministry of Defense (MOD) to some extent. It provided assessment of educational governance mechanism and analyzed last 10-years (2007-2016) input-output in terms of number of totals admitted students and the Bangladesh Journal of Medical Education 2021; 12(2); Nuruzzaman et al., publisher and licensee Association for Medical Education Bangladesh. This is an Open Access article which permits unrestricted non-commercial use, provided the original work is properly cited. database of passed graduates of the seven categories of health professionals. This study analyzed the data related to health professional education and regulation to identify the factors those influence their production. Analysis of service or deployment data was beyond the scope of 
this study. The study was conducted across the period February 2017 to October 2017.

\section{Data collection and quality check}

In consultation with the TAC, TWG adopted an extensive data collection strategy. Data collection tools were developed in consultation with the TAC and finalized after field testing. After receiving approval of the MOHFW and registering councils, data collection tools were then circulated through official government orders to the relevant academic institutions. The tools were consisting necessary indicators to fill in by themselves. Group discussions, field visits, and stakeholder's consultation were carried out as part of the study. For data collection validation and quality check, divisional and district level field visits were conducted. Data validation and quality check were carried out on timely basis by the study team to a selected number (total 24) of health professional education institutions covering all divisions. For production of maps, geospatial referencing system such as longitude and latitudes of respective educational institutions were collected. These were verified the existing MIS of the MOHFW.

\section{Data entry, analysis and validation}

To visualize the geographical presence of the health professional education institutions across the country, geographic information system (GIS) data (longitude and latitudes) were used. A robust Microsoft Office Spread Sheet (Excel) was produced. Collected data were entered that sheet, which include several indicators such as year of establishment of the institutions, location and address, divisional/regional distribution, ownership (public or private), enrollment capacity, year-wise enrollment from 2007 to 2016, year-wise graduation from 2007 to 2016, male-female distribution and nationality distribution. Entered data were analyzed and presented through using tubulation, various charts and line graphs of MS Excel. Preliminary findings were shared and validated by the key stakeholders such as principals/heads of respective institutions, faculty members, officials of MOHFW, officials from the registering bodies or councils.

\section{Results}

A total of seven categories of health professionals (i.e. medical doctors, dentist, nurse, midwives, medical assistant, medical technologist and pharmacists) and their respective institutions have been identified to map out in this mapping exercise.

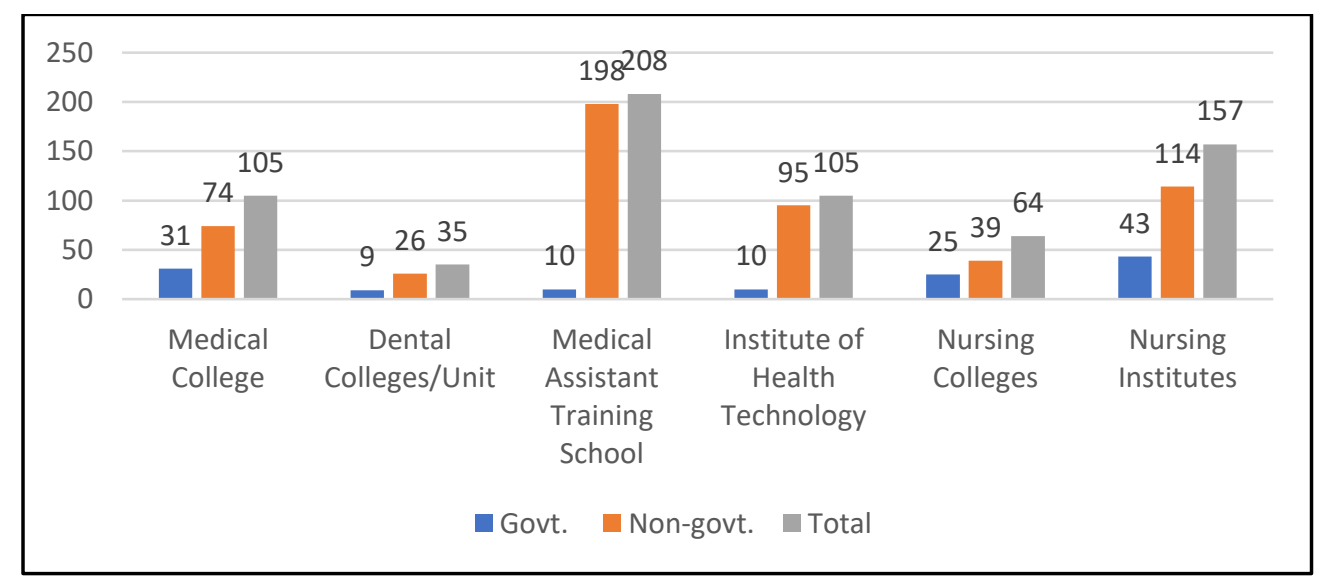

Bangladesh Journal of Medical Education 2021; 12(2); Nuruzzaman et al., publisher and licensee Association for Medical Education Bangladesh. This is an Open Access article which permits unrestricted non-commercial use, provided the original work is properly cited. 
Fig 2. Total number of educational institutions recognized by Ministry of Health up to $2016(\mathrm{~N}=674)$

A total of 674 health professional education institutions were recognized by the Ministry of Health and Family Welfare (MOHFW) in December 2016 (figure 2). Out of the total, 546 institutions $(81 \%)$ were in the non-government sector (private) and
128 institutions (19\%) were in the government sector (public). Share of medical colleges was $16 \%$ of the total, MATS 31\%, Nursing institutes were about $23 \%$ and IHT was $16 \%$ of the total.

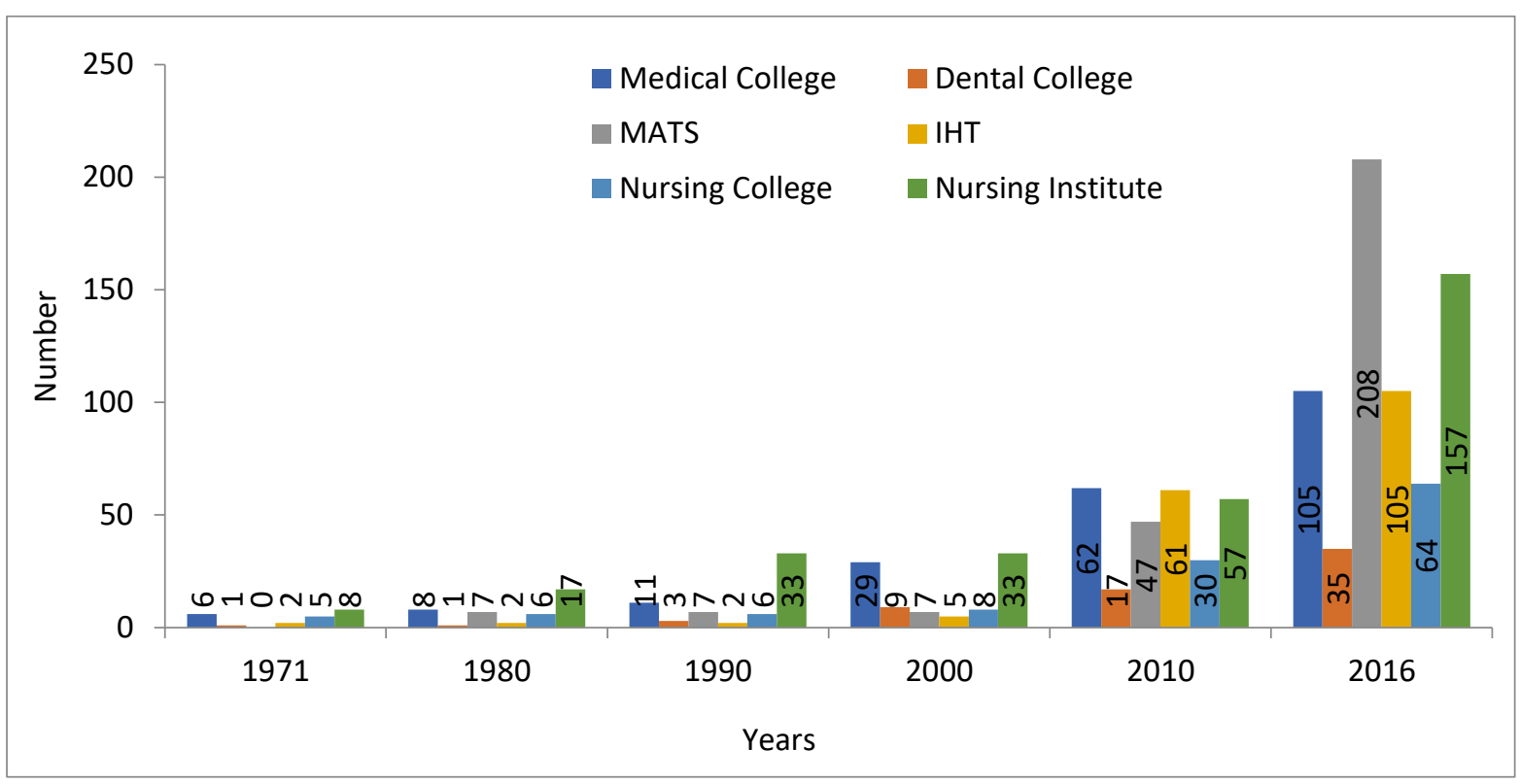

Fig 3. Establishment of educational institutions over the years 1971-2016 in Bangladesh $(\mathrm{N}=674)$

A significant increase of the number of health professional education institutions was observed between 1971 and 2016 (Figure 3), particularly the last 16 years. In 1971, the total number of key health professional education institutions was only 22 , but this had increased to 674 across the 45-year period to 2016 (equivalent to 31 times increase). The number of medical colleges was only 6 in 1971, but this increased to 29 by the year 2000 (five times increase), and then had increased further to 105 in 2016 (over 17 times increase compare to the year 1971). During 19711980, there were only eight public/government medical colleges, which increased to 30 in 2016 (about 275\% increase).

The number of dental colleges was only one in 1971 but this increased to 35 in 2016. There was no MATS in 1971 but in 2016 the number was 208. Regarding nursing college and institute, the numbers were only 5 and 8 in 1971 respectively, but that had increased up to 64 (about 13 times increase) and 157 (about 20 times increase) respectively. The number of nursing institutes has increased $275 \%$ from 57 to 157 from 2010 to 2016, contributing to increase the numbers of nurses in Bangladesh.

Bangladesh Journal of Medical Education 2021; 12(2); Nuruzzaman et al., publisher and licensee Association for Medical Education Bangladesh. This is an Open Access article which permits unrestricted non-commercial use, provided the original work is properly cited. 


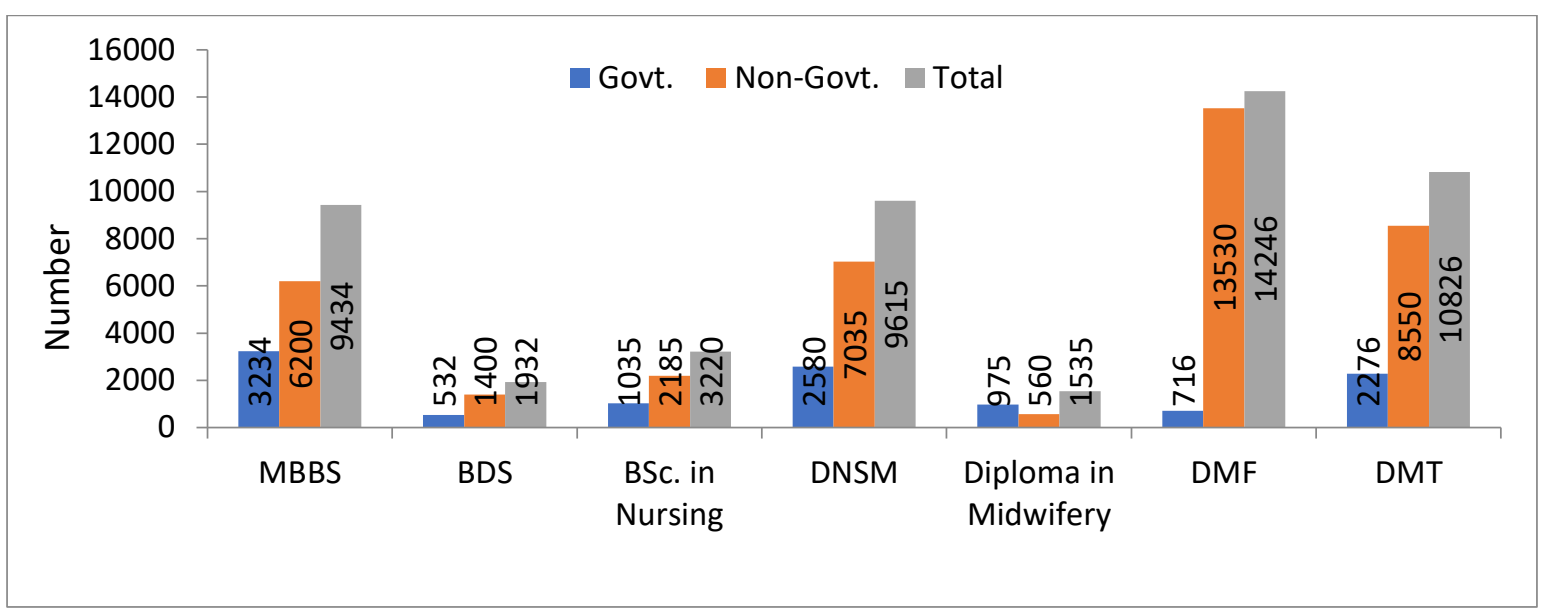

Fig 4: Total number of seats among different professional categories by 2016 ( $N=$ 50,808)

Figure 4 shows that a total of 50,808 seats had been created in all 658 health professional education institutions (recognized by MOHFW) in 2016. Out of the total, about $78 \%$ seats were in the nongovernment/private sector while the remaining $22 \%$ were in the public sector. Further, about $19 \%$ of the total number of seats belong to the MBBS students, $4 \%$ of them belong to the BDS students, $28 \%$ belong to medical assistant students, $21 \%$ belong to the medical technology students, $6 \%$ belong to the BSc nursing students, $19 \%$ belong to the Diploma in nursing and midwifery students and only $3 \%$ belong to Diploma in midwifery professionals.

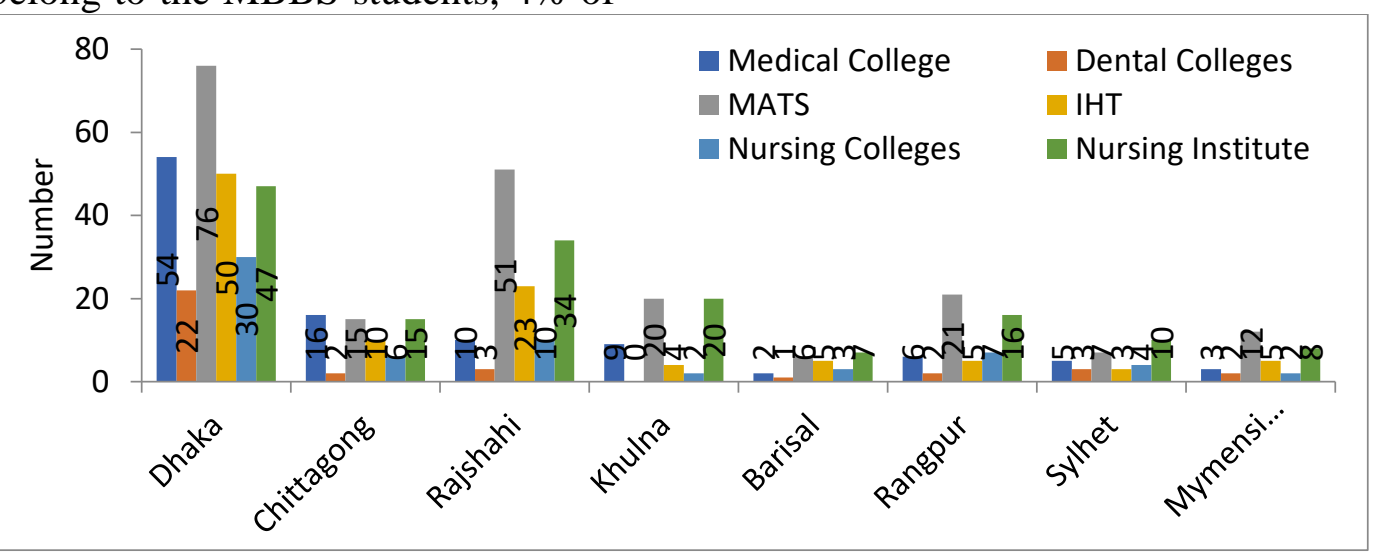

Fig 5: Distribution of health professionals' education institutions in different divisions of Bangladesh

Figure 5 denotes the distribution of HPE institutions by Division in Bangladesh, where the total number of institutions is 674 . About $41 \%$ of the total institutions are concentrated in Dhaka Division, followed by Rajshahi division $19 \%$. More than half (about $51 \%$ ) of the total medical colleges are locating in Dhaka Division. About 63\% of the total dental colleges/units (22 out of 35) are concentrating in Dhaka. A geographical plotting of those institutions is shown in Map 1.

Bangladesh Journal of Medical Education 2021; 12(2); Nuruzzaman et al., publisher and licensee Association for Medical Education Bangladesh. This is an Open Access article which permits unrestricted non-commercial use, provided the original work is properly cited. 


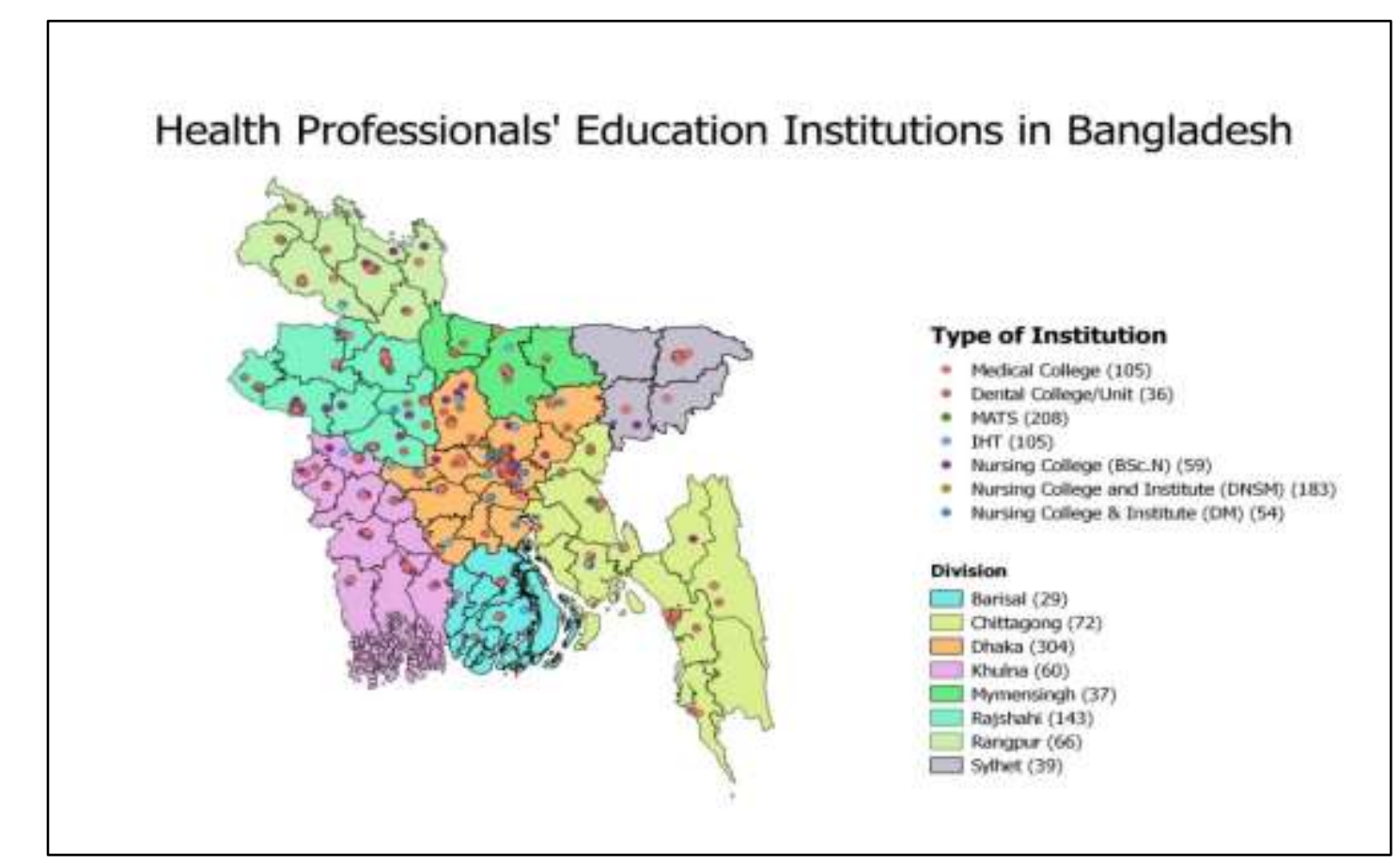

Map 1: Geographical Locations of all health Professionals Educational Institutions in Bangladesh

This is also true for IHT, Nursing College and Nursing Institute. More than half of the total medical colleges $(51 \%)$ are located in Dhaka Division and about $63 \%$ of the total dental colleges/units (22 out of 35) are concentrating in Dhaka. This has a strong implication on the density of the formally trained workforce geographically. Another important finding is that there was no Dental College or Unit was found in Khulna Division until 2016.

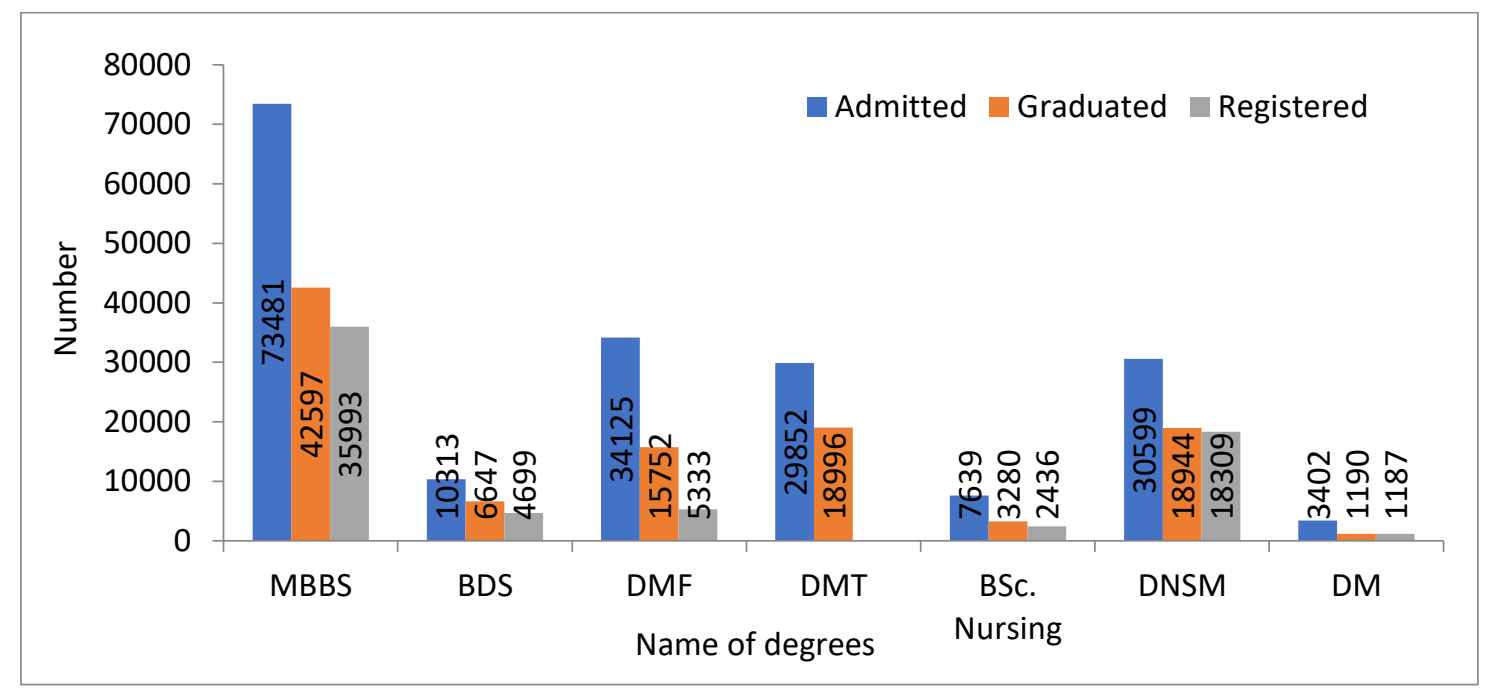

(*Diploma in Medical Technology includes all 11 disciplines including pharmacy)

Fig 6: Total number of admitted, graduated and registered/licensed with council in 2007-2016 (10 years)

Bangladesh Journal of Medical Education 2021; 12(2); Nuruzzaman et al., publisher and licensee Association for Medical Education Bangladesh. This is an Open Access article which permits unrestricted non-commercial use, provided the original work is properly cited. 
Figure 6 indicates the total number of admitted, graduated and registered/licensed professionals across the 10-year period (2007-2016). A total of 189,411 prospective health professionals were admitted in seven academic courses. At the same time, a total of 107,406 students graduated. Besides, a total of 67,957 graduated professionals were registered or licensed by the respective regulatory councils as mandatory for their professional practice. Calculation was made based on input (admission number) and output (graduation number) per year not by cohort. The number of admissions appeared high because the number of schools increased significantly from 2010 to 2016 .

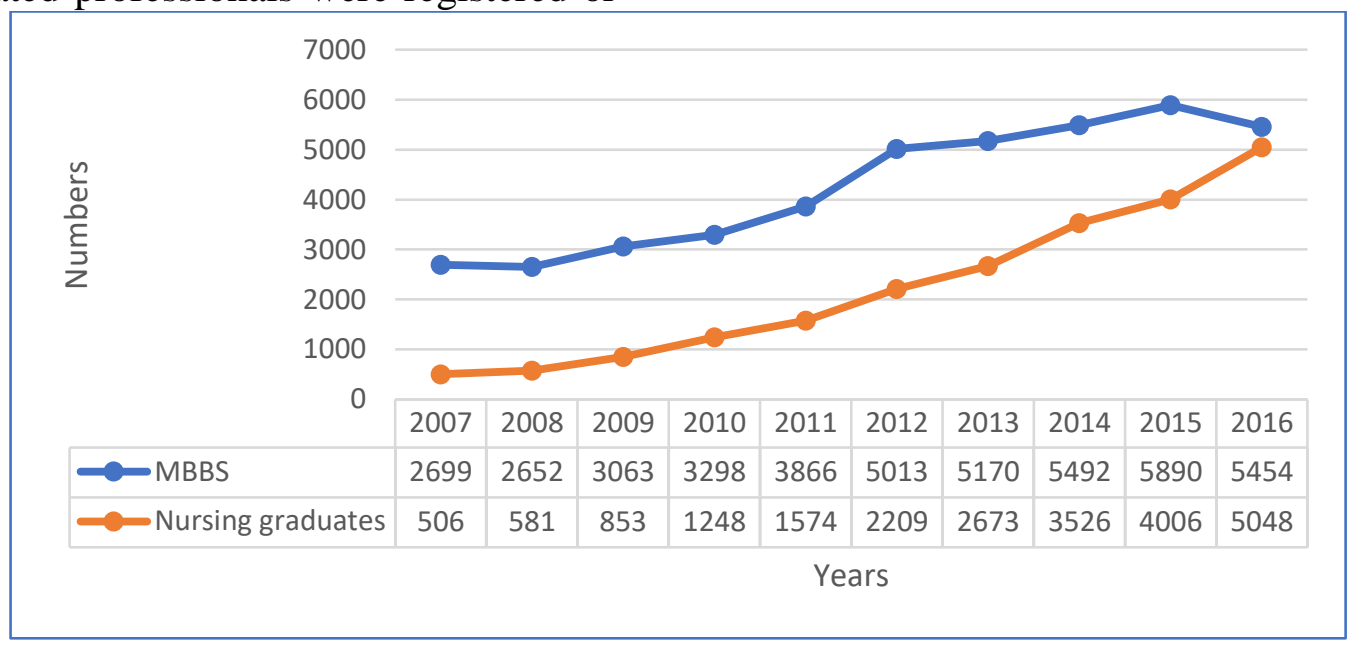

Fig 7: Yearly graduation trend of doctors and nurses (Diploma and Bachelor) during 2007-2016

A total of 42,597 medicine graduates were produced in 10 years whereas only 22,224 nurses were produced in the same time period. This means that production of the nurses was half of the doctors in 10 years period.
Though the gap of production had been narrowing down as per the Figure-7, however, the number of doctor graduates was higher than the number of nursing graduates in 2016. This will perpetuate the inverse doctor: nurse ratio in Bangladesh.

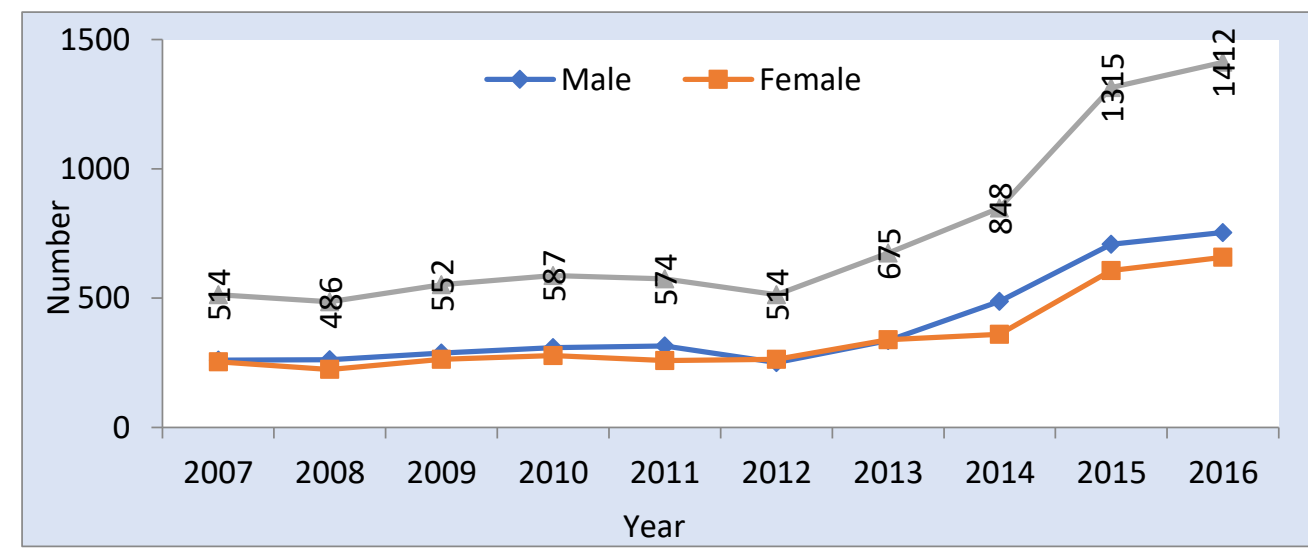

Bangladesh Journal of Medical Education 2021; 12(2); Nuruzzaman et al., publisher and licensee Association for Medical Education Bangladesh. This is an Open Access article which permits unrestricted non-commercial use, provided the original work is properly cited. 
Fig 8: Year-wise foreign nationals admitted into MBBS course during 2007-2016

Regarding nationality of the admitted MBBS students, about $10 \%(7,476)$ of the total $(73,481)$ were foreign nationals. An increasing trend of admission of the foreign-born nationals was observed during 2007-2016 (Figure-8).

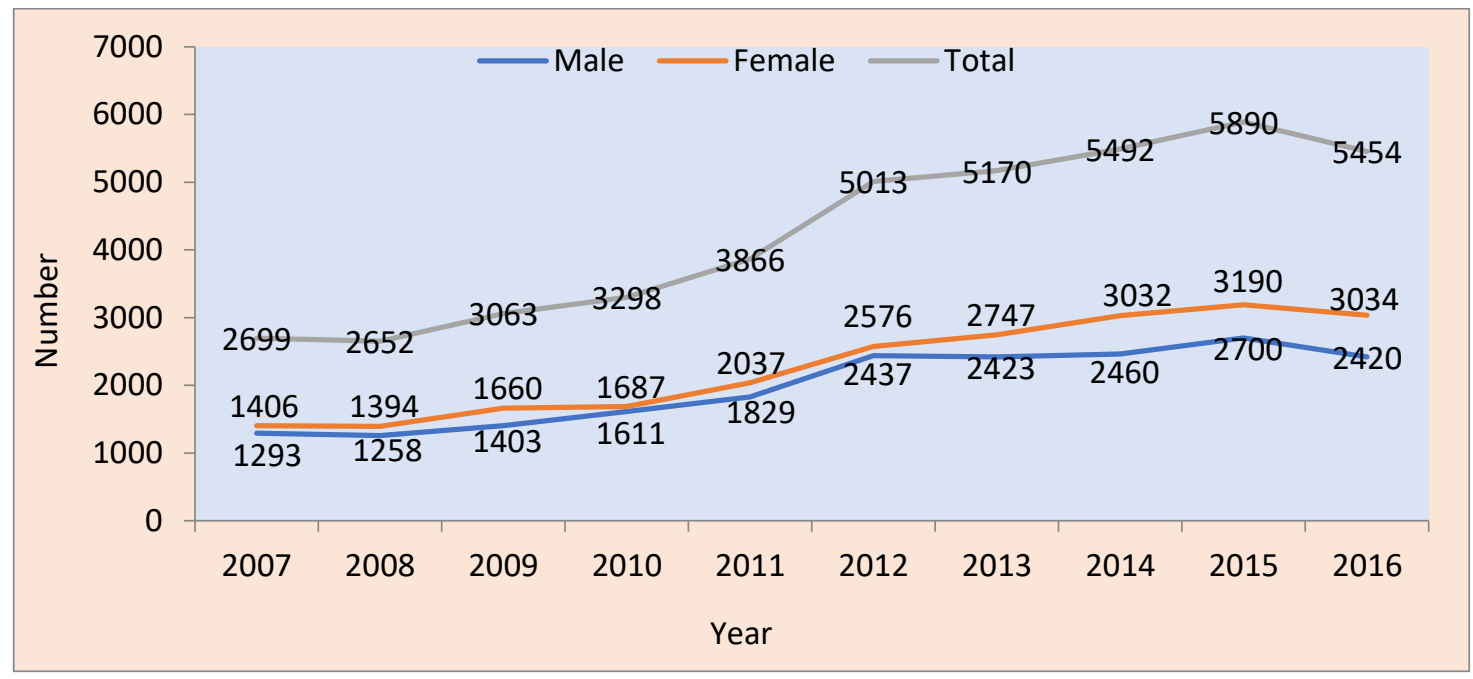

Fig 9: Male-female distribution of the MBBS graduates during 2007-2016

Regarding gender distribution of the future health professionals, about $47 \%$ of the total MBBS graduates were male and $53 \%$ were female (Figure 9). The number of females was also significant among other professional categories such as about $66 \%$ of the total BDS graduates were female and the number had been on increasing mode in the study period.

\section{Discussion}

\section{Production of health workers}

Findings from the mapping exercise clearly indicate that there has been significant increase of the number of health professional education institutions along with number of seats since 1971 (the year of independence of Bangladesh). Approximately 31 times increase of the total health professional education institutions (of the seven professional's categories) under the MOHFW has been observed. The increase has been rapid since 2010, especially in the number of the private health professional education institutions, mainly in the capital city (e.g. about $67 \%$ increase in the number of the private sector medical colleges and about $275 \%$ increase in the number of private sector nursing institutes). This has resulted in an increasing trend of the production of the health professionals every year. The increasing trend in Bangladesh will certainly help the country to overcome the critical shortage of the number of formally trained health workforce in the country.

However, it is important to note that the WHO's global HRH strategy 2030 recommends countries to have a threshold of 44.5 doctors, nurses and midwives per 10,000 population towards achievement of the SDGs. According to the latest published data by the WHO's South-East Asia Regional Office, Bangladesh has a density

Bangladesh Journal of Medical Education 2021; 12(2); Nuruzzaman et al., publisher and licensee Association for Medical Education Bangladesh. This is an Open Access article which permits unrestricted non-commercial use, provided the original work is properly cited. 
of 9.9 doctors, nurses and midwives per 10,000 population ${ }^{5}$, which is far below than the recommended density. Therefore, a strong policy intervention is required how the current pace of production would meet the gap and address the shortage of the health workforce in Bangladesh.

\section{Health workforce mix imbalance at production level}

Though significant increase of the number of establishments of new health professional institutions and production of new graduates were observed, the increase has not been proportional in different professional groups. Production of physicians (number of graduates) has been doubled compare to the production of nurses the past 10 years (2007-2016). Despite the reduction of the gap during recent years, the production of doctors is still higher than the production of nurses. In fact, Bangladesh is the only country in the South-East Asia Region with a higher number of doctors than nurses as the country has about 5.8 doctors and 3.2 nurses per 10,000 population ${ }^{5}$. This also does not align with the recommendation of the 2011 National Health Policy. The policy urges to adopt a strategy of production of doctors, nurses and paramedics at the ratio of $1: 3: 5^{14}$.

The mapping results indicate the same scenario that about $40 \%$ of the total graduates of the seven professionals are belong to the MBBS category, $15 \%$ belongs to medical assistant category, $18 \%$ to medical technologists, $21 \%$ to the diploma and BSc nurses. The MOHFW's 2019 stock of production of doctors, nurses and paramedics indicates that the country has a ratio of 2: 1: 1, which is clearly reverse of the recommendations made in the national health policy ${ }^{14}$. This creates significant skill mix imbalance and dearth shortage of nonBangladesh Journal of Medical Education 2021; 12(2); Nuruzzaman et al., publisher and licensee Association for Medical Education Bangladesh. This is an Open Access article which permits unrestricted non-commercial use, provided the original work is properly cited. physician workforce for the service delivery system ${ }^{15,16}$.

\section{Establishing health labour market platform}

Health workforce production covers supply side of the health labour market (HLM) in Bangladesh and should be an integral part of health workforce planning and projection exercise. HLM platform would help to monitor periodic production of different category of health workforce including addressing service demand. The UN High-Commission Report-2016 and WHO's Global HRH Strategy 2016-2030 suggests Member States establishing mechanism to monitor their HLM for balancing supply and demand of health workforce not only in the country but also in the Regional as well as Global level. During the mapping exercise, no such establishment for HLM was found in the country. Since there is a "Human Resources Unit" already established at the MOHFW Bangladesh, this Unit can take the lead of initiating development of the HLM framework in the country ${ }^{17}$.

\section{Acknowledging as well as regulating the private sector}

The mapping results indicate that about $78 \%$ of the total seats of all seven professionals were in the non-government private sector while the remaining $22 \%$ were in the public sector. This shows the dominance of the private sector over the public sector on educational services delivery. This is true for the service sector as well ${ }^{18}$. However, researchers as well as WHO suggest that regulation is critical to ensure quality of education and to protect people's rights in receiving quality education ${ }^{19,20}$. This is because the private 
sector mostly works for profits and sometimes compromise quality through deployment of inadequate number of qualified teachers, lacking availability of teaching materials and charging high tuition fees ${ }^{21,22}$.

\section{Geographical disparity prevails}

Geographical disparity appears in the location of health professional education institutions in Bangladesh. Out of the total educational institutions, about $41 \%$ of them have been established in Dhaka Division and rest $59 \%$ in the other seven Divisions. More than half of the total medical colleges $(51 \%)$ are located in Dhaka Division and about $63 \%$ of the total dental colleges/units (22 out of 35) are concentrating in Dhaka. There was no Dental College or Unit in Khulna Division until 2016. Studies indicate that the presence of health professional schools has a strong association with the density of formally trained workforce geographically ${ }^{23}$. WHO recommends establishing health professional Schools in outside of major cities because medical schools located in rural areas are likely to produce more physicians working in rural areas than urbanely located schools ${ }^{24,23,11}$. This necessitates adopting appropriate policy interventions in establishing health professional schools in all Divisions and remove geographical disparity.

\section{High attrition rate is anticipated between admission and graduation subject to further investigation}

The findings indicate that a total of 189,411 students admitted into the seven professional courses during 2007-2016. At the same time, a total of 107,406 students graduated. The number of admissions is found much higher than the number of graduates because the number of schools increased significantly from 2010 to 2016 . For example, regarding the number of the MBBS students and graduates, a total of 73,481 students took admission and out of them 42,597 students graduated or passed the course during 2007-2016. Many of those admitted students had been studying the course and reasonably they did not complete their respective courses during the data collection period. However, since a significant number of students did not complete the course on time, high attrition rate is anticipated. Therefore, further investigation is recommended in this regard.

\section{Feminization of the workforce is prominent}

Since 2007, production of female medical doctors and dentists has been more than the male. A gradual increase has also been observed during 2007-2016. On an average, about $14 \%$ increase of the female MBBS graduates observed in 10 years period. This appears consistent with the global trend of feminization of the health workforce ${ }^{25}$. Nevertheless, increasing production of female workforce has multiple implications on the health system such as career development, review of employment conditions and gender equity, retention at rural and hard-to-reach areas, wages mechanism, etc. ${ }^{26,27}$ This urges policy makers to provide adequate attention into this matter so that the health system could be made ready for absorbing female workforce in the near future.

\section{Need of a comprehensive education management information system}

This mapping exercise reveals that in Bangladesh, health workforce production data are credibly available at agency/institution level (colleges, schools, training centres etc.). But they are not readily and comprehensively available at

Bangladesh Journal of Medical Education 2021; 12(2); Nuruzzaman et al., publisher and licensee Association for Medical Education Bangladesh. This is an Open Access article which permits unrestricted non-commercial use, provided the original work is properly cited. 
one central location or one place at national level [28]. Government of Bangladesh is committed to a Digital Bangladesh by 2021. GOB through the Ministry of Information and Communication Technology (MOICT) finalized and adopted the National ICT Policy-2018 and along with its action plan ${ }^{29}$. But digitalization of health professional education management systems is still way from its implementation [28]. Until today, paper-based data collection is in place and this makes decision making lengthy and complex.

The "Global Human Resources for Health Strategy: Workforce 2030" (2016) promotes to capitalize the opportunities of ICT to build the competencies among health workers for better alignment of education with healthcare delivery ${ }^{30}$. The United Nation's High-Level Commission report (2016) recommended providing especial emphasis on $\mathrm{ICT}^{4}$. It urges to harness the power of cost-effective ICTs for enhancement of health education, peoplecentered health services and health information systems. Therefore, it is important that the government takes steps to establish a comprehensive education management information system (EMIS) at central level with interoperability provision extended to the field levels so that timely and quick report could be generated to assist formulation of comprehensive health workforce plan for the present and the future of Bangladesh.

\section{Strengths and limitations}

This study had a number of strengths. First, the government itself for the first time commissioned this study through establishing a national level technical advisory committee and a working group with technical assistance from WHO Bangladesh. Second, geographic Bangladesh Journal of Medical Education 2021; 12(2); Nuruzzaman et al., publisher and licensee Association for Medical Education Bangladesh. This is an Open Access article which permits unrestricted non-commercial use, provided the original work is properly cited. information system was used to map out location of the educational institutions throughout the country, which ensured accuracy of the maps. Third, the study team used both qualitative and quantitative methods for primary data collection, which complemented each other for bringing data accuracy. Fourth, WHO technical officers and the MOHFW officials were directly involved in the field level data quality checks.

However, there were also few limitations. This mapping assessment covered only the health professional education institutions (HPEIs) recognized by the Ministry of Health and the Ministry of Defense. It did not cover those educational institutions, which offer courses related to alternative medical care (AMC) such as Bachelor and Diploma in Homeopathy, Unani and Ayurveda. This assessment also did not cover the institutions under the authority of the Ministry of Education (MOE), though those were in limited scale.

\section{Conclusion and Recommendations}

The study indicates that Bangladesh has increased production of different categories of health workforce over the past ten years, mainly at the expansion of the private sector and production of the medical doctors was the highest compare to any other professional categories. This raises few concerns - whether the increase of the production is happening in a right or planned way? Whether this increase is fast enough to address the critical shortages of health workers to achieve UHC in Bangladesh remains unclear. Furthermore, since the economy of Bangladesh has been on a progressive mode, it is time for the country to conduct comprehensive health labour market analysis to assess the supply and demand of the health workers categorywise. Comprehensive and evidence-based 
health workforce planning and policy making are critical to meet the commitment of achieving Universal Health Coverage in Bangladesh.

\section{Acknowledgements}

The authors express their gratitude to the World Health Organization Country Office, Bangladesh for initiating the project, as well as to the Directorate General of Health Services under the Ministry of Health and Family Welfare, Bangladesh for implementing it. We are sincerely thankful to Professor Dr Md Ahsan Habib, Director, Medical Education, Directorate General of Medical Education for his guidance and facilitation during the field work. Our heartfelt thanks go to Professor James Buchan, Faculty of Health, University of Technology, Australia for his kind inputs to the first draft. Finally, we would like to extend our sincere gratitude to all Technical Advisory Committee members and Technical Working Group members for their contributions throughout the study period.

\section{Author's Contributions}

Md Nuruzzaman (MN) and Tomas Zapata (TZ) conceived and designed the study. MN wrote the first draft of the manuscript. MN and Md Masudur Rahman (MMR) carried out the data analyses of the manuscript. TZ, Md Humayun Kabir Talukder (MHKT), and MMR provided technical inputs in the inception phase and throughout the study process. MN, TZ, MHKT and MMR thoroughly reviewed the manuscript and contributed substantially with the necessary revision. $\mathrm{MN}, \mathrm{TZ}$ and MHKT again reviewed the manuscript and prepared for the final submission. All authors approved the final manuscript.

\section{Availability of data and materials}

The datasets generated and/or analysed during this study are not publicly available due to joint ownership of the data, but they are available from the corresponding author on reasonable request.

\section{Map disclaimer}

The depiction of boundaries on this map does not imply the expression of any opinion whatsoever on the part of the Journal concerning the legal status of respective country, territory, jurisdiction or area or of its authorities. This map is provided without any warranty of any kind, either express or implied.

\section{Competing interests}

Authors declare no conflict of interest.

\section{Patient consent for publication}

Not required.

\section{Funding}

This publication is based on the assessment conducted by the Directorate General of Health Services, Ministry of Health and Family Welfare, Bangladesh, funded by the World Health Organization Bangladesh Country Office. The findings and conclusions contained within are those of the authors and do not necessarily reflect positions or policies of the World Health Organization and Ministry of Health and Family Welfare, Bangladesh.

\section{References}

1 "Working together for health The World Health Report 2006," The World Health Organization, Geneva, 2006.

2 Campbell, J., Buchan, J., Cometto, G., David, B., Dussault, G., Fogstad, H., Fronteira, I., Lozano, R., Nyonator, F., Pablos-Mendez, A., Quain E E., Starrs, A., and Tangcharoensathien, V., "Human resources for health and universal

Bangladesh Journal of Medical Education 2021; 12(2); Nuruzzaman et al., publisher and licensee Association for Medical Education Bangladesh. This is an Open Access article which permits unrestricted non-commercial use, provided the original work is properly cited. 
health coverage: fostering equity and effective coverage," Bulletin of the World Health Organization, vol. 91, no. 91, pp. 853-63, 2013. doi: 10.2471/BLT.13.118729

3 Global Strategy on Human Resources for Health: Workforce 2030, Geneva: World Health Organization, 2016.

4 Working for health and growth: investing in the health workforce. Report of the High-Level Commission on Health Employment and Economic Growth, Geneva: World Health Organization, 2016.

5 Decade for health workforce strengthening in the South-East Asia Region 2015-2024 Mid-term review of progress, 2020, New Delhi: World Health Organization, Regional Office for South-East Asia; 2018. Licence: CC BY-NC-SA 3.0 IGO, 2020.

6 "HRH Data Sheet-2019," Ministry of Health and Family Welfare, Government of Bangladesh, Dhaka, 2019.

7 Bangladesh Health Workforce Strategy-2015, Dhaka: Government of Bangladesh, Ministry of Health and Family Welfare, 2015.

8 Non Government Medical College Establishment and Implementation Policy-2011 (Revised), Dhaka: Government of Bangladesh, Ministry of Health and Family Welfare, 2011.

9 "Unsatisfactory state of private medical education," The Daily Star, 27 March 2019. [Online]. Available: www.thedailystar.net/editorial/news /unsatisfactory-state-privatemedical-education-1720681. [Accessed 30 October 2020].

10 ALLOCATION OF BUSINESS AMONG THE DIFFERENT MINISTRIES AND DIVISIONS (Schedule I of the Rules of Business, 1996), Dhaka: Government of Bangladesh Cabinet Division, 2012.

11 Green, A E., Fettes D L. and Aarons, G A. "A Concept Mapping Approach to Guide and Understand Dissemination and Implementation," Behav Health Serv Res. 2012 October ; 39(4):; vol. 39, no. 4, p. 362-373, October 2012. doi:10.1007/s11414-012-9291-1

12 Appiagyei, A A., Kiriinya, R N., Gross J M., Wambua, D N., Oywer, E O., Kamenju, A K., Higgins, M K., Riley P L., and Rogers M F., "Informing the scale-up of Kenya's nursing workforce: a mixed methods study of factors affecting pre-service training capacity and production," Human Resources for Health, vol. 12, no. 47, pp. 1478-4491, 2014. doi:10.1186/1478-4491-12-47

13 Castro Lopes S, Guerra-Arias M, Buchan J, Pozo-Martin F, Nove A. "A rapid review of the rate of attrition from the health workforce," Human Resources for Health, vol. 15, no. 21, 2017. doi: 10.1186/s12960-017-0195-2.

14] National Health Policy-2011 (in Bangla), Dhaka: Government of Bangladesh, Ministry of Health and Family Welfare, 2011.

Bangladesh Journal of Medical Education 2021; 12(2); Nuruzzaman et al., publisher and licensee Association for Medical Education Bangladesh. This is an Open Access article which permits unrestricted non-commercial use, provided the original work is properly cited. 
15 Joarder T, Tune SNBK, Nuruzzaman $\mathrm{M}$, et al., "Assessment of staffing needs for physicians and nurses at Upazila health complexes in Bangladesh using WHO workload indicators of staffing need (WISN) method," BMJ Open, vol. 10, no. 10, p. e035183, 2020. doi:10.1136/bmjopen-2019-035183.

16 Ahmed SM, Hossain MA, Rajachowdhury AM, Bhuiya AU., "The health workforce crisis in Bangladesh: shortage, inappropriate skill-mix inequitable distribution," Hum Resour Health, vol. 9, no. 3, pp. -, 2011. doi: 10.1186/1478-4491-9-3.

17 Human Resources Development Operational Plan 2017-2022 under the fourth sector programme, Dhaka: Government of Bangladesh, Ministry of Health and Family Welfare, 2017.

18 Ahmed SM., Alam, BB., Anwar, I., Begum, T., Huque, R., Khan, J AM., Naban, J., and Osman, F A., Bangladesh Health System Review, Dhaka: World Health Organization, 2015., 2015.

19 Transforming and Scaling Up Health Professionals Education and Training: World Health Organization Guidelines 2013, Geneva: World Health Organization , 2013.

20 V. R. Keshri, V. Sriram and R. Baru, "Reforming the regulation of medical education, professionals and practice in India," BMJ Global Health, vol. 5, p. e002765., 2020. doi: 10.1136/bmjgh-2020-002765
21 Mackintosh, M., Channon, A., Karan, A., Selvaraj, S., Zhao, H., and Cavagnero, E., "What is the private sector? Understanding private provision in the health systems of low-income and middle-income countries," Lancet , vol. 388, pp. 596-605, 2016. http://dx.doi.org/10.1016/S01406736(16)00342-1

22 Wadge, Hester et al., "How to harness the private sector for universal health coverage," The Lancet, vol. 390, no. 10090, pp. e19 - e20, 2017. DOI:https://doi.org/10.1016/S01406736(17)31718-X

23 "Global policy recommendations increasing access to health workers in remote and rural areas through improved retention," World Health Organization, Geneva, 2010.

24 Buchan, J., Couper, I. D., Tangcharoensathien, V., Thepannya, K., Jaskiewicz, W., Perfilieva, G., \& Dolea, C. (2013). "Early implementation of WHO recommendations for the retention of health workers in remote and rural areas," Bull World Health Organ., vol. 91, no. 11, p. 834-40, 2013. doi.org/10.2471/BLT.13.119008.

25 Shannon G, Minckas N, Tan D, Haghparast-Bidgoli H, Batura N, Mannell J., "Feminisation of the health workforce and wage conditions of health professions: an exploratory analysis," Human Resources for Health, vol. 17, no. 72, 2019. doi: 10.1186/s12960-0190406-0.

Bangladesh Journal of Medical Education 2021; 12(2); Nuruzzaman et al., publisher and licensee Association for Medical Education Bangladesh. This is an Open Access article which permits unrestricted non-commercial use, provided the original work is properly cited. 
26 Boniol M, McIsaac M, Xu L, Wuliji T, Diallo K, Campbell J., "Gender equity in the health workforce: analysis of 104 countries. Working paper 1," World Health Organization (WHO/HIS/HWF/Gender/WP1/201 9.1).Licence: CC BY-NC-SA 3.0 IGO., Geneva, 2019.

27 WOMEN AND MEN IN BANGLADESH Facts and Figures 2018, Dhaka, Bangladesh: Bangladesh Bureau of Statistics, Swedish International Development Cooperation Agency (Sida), Statistics Sweden and UN Women, March 2019.

28 Mapping of health professional education institutions in Bangladesh, Dhaka: Directorate General of Health Services, Medical Education and Health Manpower Development and World Health, 2018.

29 National Information and Communication Technology Policy 2018 (In Bangla), Dhaka: Government of Bangladesh, Information and Communication Technology Division, 2018.

30 Frenk J, Chen L, Bhutta ZA, Cohen J, Crisp N, Evans T, Fineberg H, Garcia P, Ke Y, Kelley P, Kistnasamy B, Meleis A, Naylor D, Pablos-Mendez A, Reddy S, Scrimshaw S, Sepulveda J, Serwadda D, Zurayk H., "Health professionals for a new century: transforming education to strengthen health systems in an interdependent world," Lancet, vol. 376, pp. 1923-58, 2010. doi: 10.1016/S0140-6736(10)618545.

Bangladesh Journal of Medical Education 2021; 12(2); Nuruzzaman et al., publisher and licensee Association for Medical Education Bangladesh. This is an Open Access article which permits unrestricted non-commercial use, provided the original work is properly cited. 